\title{
Function and Protein Expression of Potassium Channels in Mesenteric Resistance Arteries Isolated from 2K-1C Hypertensive Rats
}

\section{Alice V Araújo ${ }^{1 *}$, Marcella D Grando ${ }^{2}$, Roberto S DA Silva ${ }^{2}$ and Lusiane M Bendhack ${ }^{2}$}

${ }^{1}$ School of Medicine of Ribeirão Preto, University of São Paulo, Brazil

${ }^{2}$ Faculty of Pharmaceutical Sciences of Ribeirão Preto, University of São Paulo, Brazil

\begin{abstract}
The present study aimed to evaluate the $\mathrm{K}^{+}$channels activation in vascular relaxation induced by the nitric oxide (NO) donors ruthenium-derived complex (Terpy) and sodium nitroprusside (SNP), as well as its protein expression, on mesenteric resistance arteries (MRA) isolated from renal hypertensive rats (2K-1C) and sham-operated rats (Sham). The NO donors Terpy and SNP induced relaxation with similar efficacy in isolated MRA from both $2 \mathrm{~K}-1 \mathrm{C}$ and Sham rats, although SNP was more potent than Terpy. The maximum relaxation induced by Terpy was decreased when the voltagegated potassium channels were blocked in MRA from Sham, but not in $2 \mathrm{~K}-1 \mathrm{C}$ rat arteries. The blockade of ATP-sensitive $\left(\mathrm{K}_{\mathrm{ATP}}\right)$, big and small conductance $\mathrm{Ca}^{2+}$-activated $\left(\mathrm{SK}_{\mathrm{Ca}}\right)$ or inward rectifier $\left(\mathrm{K}_{\mathrm{IR}}\right)$ potassium channels decreased the maximum relaxation induced by Terpy in MRA from Sham and $2 \mathrm{~K}-1 \mathrm{C}$ rats. However, the maximum relaxation induced by SNP was inhibited in Sham but not in $2 \mathrm{~K}-1 \mathrm{C}$ rats when the big conductance calcium-activated potassium channel was blocked. However, it remained the same when the other potassium channels were blocked. The protein expression of the $\mathrm{SK}_{\mathrm{Ca}}$ and $\mathrm{K}_{\mathrm{ATP}}$ were not altered in $2 \mathrm{~K}-1 \mathrm{C}$ hypertensive rat MRA whereas the expression of $\mathrm{KV}$ and $\mathrm{BK}$ augmented in MRA from $2 \mathrm{~K}-1 \mathrm{C}$ rats. Therefore, the potassium channels play different role on the relaxation induced by SNP and Terpy. The activation of different potassium channels and the protein expression of potassium channels may be differently modulated in arteries from $2 \mathrm{~K}-1 \mathrm{C}$ hypertensive rats when compared to normotensive rats.
\end{abstract}

Keywords: Hypertension; Mesenteric resistance arteries; Potassium channels; NO donor

\section{Introduction}

Potassium channels play a central role in the maintenance of the electrical potential across the plasma membrane in smooth muscle cells [1]. In arterial smooth muscle, the potassium channel activity is linked to contractile tone. The factors that regulate the activity of potassium channels may have major influences on tone and also on blood vessel diameter and consequently on vascular resistance, blood flow and blood pressure [1].

At least four different subtypes of potassium channels have been identified in arterial smooth muscle cells, which include the inward rectifier $\left(\mathrm{K}_{\mathrm{IR}}\right)$, voltage-gated $\left(\mathrm{K}_{\mathrm{V}}\right)$, ATP gated $\left(\mathrm{K}_{\mathrm{ATP}}\right)$ and $\mathrm{Ca}^{2+}$-gated potassium $\left(\mathrm{K}_{\mathrm{Ca}}\right)$ channels. Potassium channels from different vascular beds, different blood vessels size (i.e. conduit versus resistance blood vessels) or even different segments of the same artery have different properties [2-5]. These differences may account for the differences in their responses to physiological, pharmacological, or pathological stimuli [6]. Therefore, ion channels in the cells which make up the walls of vessels in the microcirculation display unique function or expression patterns that remain largely unexplored [7].

Diseases like hypertension may induce changes in the function and/ or expression pattern of the potassium channels. As recently shown by Matsumoto et al. [8], the defective activation of $\beta$-adrenoceptorsmediated relaxation in mesenteric arteries from DOCA-salt hypertensive rats could be attributed to impairment in KCa channels. Moreover, the resting membrane potential of vascular smooth muscle cells is reported to be more depolarized in arteries from hypertensive versus normotensive animals $[9,10]$. The effect of hypertension on resting membrane potential may be more profound in smaller resistance vessels, especially in vascular beds that play a significant role in the regulation of peripheral resistance [11]. It suggests that small arteries $(<200 \mu \mathrm{m}$ in diameter) from physiologically relevant vascular beds (renal, mesenteric, and cerebral) are altered in hypertension and play a significant role in the regulation of peripheral resistance [11].
Therefore, generalizing the role of potassium channels is extremely dangerous. It is clear that more information is needed on potassium channel expression profiles in different arterial preparations before general conclusions can be drawn about channel alterations during hypertension [12]. In this study, we aimed to verify the functional and expressional pattern of potassium channels in mesenteric resistance arteries isolated from $2 \mathrm{~K}-1 \mathrm{C}$ hypertensive rats.

\section{Methods}

\section{Animals}

Male rats $(180-200 \mathrm{~g})$ were maintained in standard conditions, including $12 \mathrm{~h}$ light/dark cycle and free access to standard rat chow and water. Experimental protocols followed standards and policies of the Animal Care and Use Committee of University of São Paulo (044/2008). Briefly, rats were anesthetized with tribromoethanol (2.5 mg.kg-1 ip). A small midline laparotomy was then performed and a silver clip $(0.2 \mathrm{~mm}$ internal diameter) was placed on the left renal artery. The abdomen was closed in two layers, and the animals were allowed to recover. Sham-operated animals were submitted to laparotomy only. After the surgery, the animals were treated with a unique dose of oxytetracyclin (200 mg.kg ${ }^{-1}$, i.m.) in order to minimize the risk of infection. Six weeks after the surgery, the systolic arterial pressure (SAP) was measured by

*Corresponding author: Dr. Alice Valença Araújo, Laboratory of Pharmacology, Faculty of Pharmaceutical Sciences of Ribeirão Preto USP, Ribeirão Preto, Brazil, Tel: +55-16-36024704; Fax: +55-16-36024880 E-mail: alicevaraujo@yahoo.com.br

Received January 27, 2014; Accepted April 02, 2014; Published April 04, 2014

Citation: Araújo AV, Grando MD, Silva RSDA, Bendhack LM (2014) Function and Protein Expression of Potassium Channels in Mesenteric Resistance Arteries Isolated from 2K-1C Hypertensive Rats. J Hypertens 3: 146. doi:10.4172/2167-1095.1000146

Copyright: (c) 2014 Araújo AV, et al. This is an open-access article distributed under the terms of the Creative Commons Attribution License, which permits unrestricted use, distribution, and reproduction in any medium, provided the original author and source are credited. 
tail-cuff method and the rats were considered to be hypertensive when SAP was higher than $160 \mathrm{mmHg}$.

\section{Vascular reactivity studies}

The rats were anesthetized and killed by decapitation. The mesentery was removed and immediately placed in a Petri plate containing cold $\left(4^{\circ} \mathrm{C}\right)$ Krebs solution with the following composition (in $\left.\mathrm{mM}\right): \mathrm{NaCl}$ 118.0, $\mathrm{KCl} 5.9, \mathrm{KH}_{2} \mathrm{PO}_{4} 1.2, \mathrm{CaCl}_{2} 2.5, \mathrm{MgSO}_{4} 1.2, \mathrm{NaHCO}_{3} 24.9$, dextrose 11.0, $\mathrm{pH}$ 7.4. The second or third order mesenteric arteries (internal diameter 200-300 $\mu \mathrm{m}$ ) were dissected, cleaned of fat and connective tissue, cut into $2 \mathrm{~mm}$ long rings and mounted in a MulvanyHalpern Myograph for isometric tension changes recordings. The arteries were normalized to a transmural pressure of $100 \mathrm{mmHg}$ [13]. To test the viability of the preparations, the contraction of the arterial segments was stimulated twice with $120 \mathrm{mM} \mathrm{KCl}$. The endothelium was removed by gently rubbing the internal surface of the arteries with a human hair and the removal was confirmed by the absence of relaxation to acetylcholine $(10 \mu \mathrm{M})$ in preparations contracted with phenylephrine (PE $10 \mu \mathrm{M})$.

Cumulative concentration-effects curves for the NO donors sodium nitroprusside (SNP) and $\left[\mathrm{Ru}(\text { terpy)(bdq)NO }]^{3+}\right.$ (Terpy) were constructed in Sham and $2 \mathrm{~K}-1 \mathrm{C}$ rat mesenteric resistance arteries contracted with $10 \mu \mathrm{M}$ PE. In order to verify the potassium channels subtypes involved in this relaxation, the concentration-effect curves for SNP or Terpy were constructed in the presence of the following potassium channel blockers: 4-Aminopiridine ( $1 \mathrm{mM}$ 4-AP for $\mathrm{K}_{\mathrm{v}}$ ); Glibenclamide $\left(3 \mu \mathrm{M}\right.$, for $\left.\mathrm{K}_{\mathrm{ATP}}\right)$; Apamin $\left(1 \mu \mathrm{M}\right.$, for $\left.\mathrm{SK}_{\mathrm{Ca}}\right)$; paxilline $(1$ $\mu \mathrm{M}$, for $\left.\mathrm{BK}_{\mathrm{Ca}}\right)$ and barium chloride $\left(30 \mu \mathrm{M} \mathrm{BaCl}_{2}\right.$ for $\left.\mathrm{K}_{\mathrm{IR}}\right)$.

The NO donor [Ru(terpy)(bdq)NO] ${ }^{3+}$ (Terpy) was synthesized by the Analytical Chemistry Laboratory at the Department of Physics and Chemistry of the Faculty of Pharmaceutical Sciences of Ribeirão Preto, University of São Paulo, as previously described by de Lima et al. [14].

\section{Western blotting}

The rats were anesthetized and killed by decapitation. The mesenteric bed was removed and placed immediately in a Petri plate containing cold $\left(4^{\circ} \mathrm{C}\right)$ Krebs solution with the following composition (in $\mathrm{mM}$ ): $\mathrm{NaCl}$ 118.0, $\mathrm{KCl} 5.9, \mathrm{KH}_{2} \mathrm{PO}_{4} 1.2, \mathrm{CaCl}_{2} 2.5, \mathrm{MgSO}_{4}$ 1.2, $\mathrm{NaHCO}_{3} 24.9$, dextrose 11.0, $\mathrm{pH}$ 7.4. The mesenteric bed was dissected and cleaned of fat and connective tissue. The mesenteric artery, as well as the firstorder branch, was discarded. The remaining tissue was immediately frozen in liquid nitrogen. Each sample was homogenized in protein ice-cold lysis buffer RIPA (Tris-HCl $65.2 \mathrm{mM}$; NaCl 154 mM; NP-40 $1 \%$; sodium deoxycolate $0.25 \%$; EDTA $0.8 \mathrm{mM}$ ). Homogenates were centrifuged at $10,000 \mathrm{rpm}$ at $4^{\circ} \mathrm{C}$ for $10 \mathrm{~min}$, to remove tissue debris. Protein concentrations in the samples were determined by the Bradford method (Bio-Rad Protein Assay). Protein from the tissue samples $(30 \mu \mathrm{g} /$ well) were separated on $8-10 \%$ SDS-PAGE and transferred to a nitrocellulose membrane. Membranes were blocked for $60 \mathrm{~min}$ with $5 \%$ nonfat milk in tris-buffered solution, at room temperature. Membranes were incubated overnight with goat polyclonal primary antibody against the subunit $\mathrm{K}_{\mathrm{v} 1.5}$ of $\mathrm{K}_{\mathrm{v}}$ (1:5000, Chemicon, catalog number $\mathrm{AB} 5182)$, or $\mathrm{BK}_{\mathrm{Ca}}(1: 5000, \mathrm{BD}$ Biosciences, catalog number 611248), or $\mathrm{SK}_{\mathrm{Ca}}$ (1:5000, Santa Cruz Biotechnology, catalog number SC-28621), or subunits SUR 2B (1:1000, Santa Cruz Biotechnology, catalog number SC-5793) or $\mathrm{K}_{\mathrm{IR}} 6.1$ of $\mathrm{K}_{\mathrm{ATP}}$ (1:1,000, Santa Cruz Biotechnology, catalog number SC-11224), at 4oC. Membranes were then incubated with a HRP-conjugated secondary antibody (rabbit, $1: 1,000$ for $\mathrm{K}_{\mathrm{V}}$; mouse, $1: 2,000$ for $\mathrm{BK}_{\mathrm{Ca}}$; rabbit 1:2,000 for $\mathrm{SK}_{\mathrm{Ca}}$ or goat
1:4,000 for the subunits of $\mathrm{K}_{\mathrm{ATP}}$ ) for $2 \mathrm{~h}$ at room temperature, followed by chemiluminescence labeling (ECL, GE Healthcare) for $2 \mathrm{~min}$. Bands were detected by using a film developer (Image Quant 350 GE). To determine loading consistencies, each membrane was incubated with antibody against mouse $\beta$-actin (Santa Cruz Biotechnology, catalog number SC-47778), and data were normalized by $\beta$-actin values. The abundance of the proteins was quantified by densitometry (Image J).

\section{Drugs and reagents}

$\mathrm{NaCl}, \mathrm{KCl}, \mathrm{MgSO}_{4}, \mathrm{KH}_{2} \mathrm{PO}_{4}, \mathrm{CaCl}_{2}$ and $\mathrm{NaHCO}_{3}$ were purchased from Labsynth. D-glucose was purchased from Vetec Química. The drugs phenylephrine, acetylcholine, 4-aminopiridine, glibenclamide, apamin, paxilline, and barium chloride were purchased from SigmaAldrich (Sigma-Aldrich Co.).

The drugs phenylephrine, acetylcholine, 4-amminopiridine, glibenclamide, apamin and barium chloride were dissolved in distilled water. Paxilline was dissolved in DMSO. Terpy was diluted in a solution of DMSO $10 \%$. The final concentration of DMSO did not exceed $0.01 \%$ in the incubation bath.

\section{Data analysis}

Data are expressed as mean \pm SEM, with $\mathrm{n}$ indicating the number of animals.

For the functional studies, the maximum effect (ME) was considered as the maximal amplitude response reached in the concentrationeffect curves for the relaxant agent. Data are represented as percentage of the maximum effect, in order to normalize the relaxation. The concentration of the agent producing half-maximal relaxation amplitude $\left(\mathrm{EC}_{50}\right)$ was determined after logarithmic transformation of the normalized concentration-effect curves, and $\mathrm{EC}_{50}$ values are reported as the negative logarithm $\left(\mathrm{D}_{2}\right)$ of the mean of individual values for each tissue. Statistical analysis was performed by one-way ANOVA with Newman Keul's post-hoc test, using the software Prism Graphpad 5.0.

For the western blotting studies, the statistical analysis was performed by unpaired t Student test, using the Prism Graphpad 5.0.

In all the cases, a $p$ value $<0.05$ was considered statistically significant.

\section{Results}

\section{Vascular reactivity}

The NO donors SNP and Terpy induced relaxation with similar efficacy (ME) in isolated mesenteric resistance arteries from both sham and hypertensive $2 \mathrm{~K}-1 \mathrm{C}$ rats (SNP, Sham: $96.2 \pm 0.9 \%, \mathrm{n}=5 ; 2 \mathrm{~K}-1 \mathrm{C} 87.3$ $\pm 3.5 \%, \mathrm{n}=7$; Terpy Sham: $93.9 \pm 1.3 \%, \mathrm{n}=7$; $2 \mathrm{~K}-1 \mathrm{C}$ : $93.2 \pm 1.6 \%, \mathrm{n}=7$ ). However, SNP was more potent in inducing relaxation than Terpy as shown by the $p \mathrm{D}_{2}$ values (SNP, Sham: $6.71 \pm 0.12, \mathrm{n}=5 ; 2 \mathrm{~K}-1 \mathrm{C}$ : $6.90 \pm$ 0.30, $\mathrm{n}=7$; Terpy Sham: $4.76 \pm 0.14, \mathrm{n}=7 ; 2 \mathrm{~K}-1 \mathrm{C}: 4.68 \pm 0.15, \mathrm{n}=7)$. It can be noticed in the Figure 1 that the curve profile is also different. The maximum relaxation induced by SNP was not altered by the voltagedependent potassium channel blocker, 4-aminopiridine (4-AP), both in Sham (ME: $94.5 \pm 2.8 \%, p \mathrm{D}_{2}: 6.40 \pm 0.30, \mathrm{n}=7$, Figure $1 \mathrm{~A}$ ) and $2 \mathrm{~K}-1 \mathrm{C}$ rat arteries (ME: $92.3 \pm 7.2 \%, p \mathrm{D}_{2}: 7.72 \pm 0.51, \mathrm{n}=4$, Figure $1 \mathrm{C}$ ).

The maximum relaxation induced by Terpy was decreased by the voltage-dependent potassium channel blocker 4-aminopiridine (4$\mathrm{AP}$ ), in mesenteric resistance arteries from Sham (ME: $70.9 \pm 6.6 \%$, 

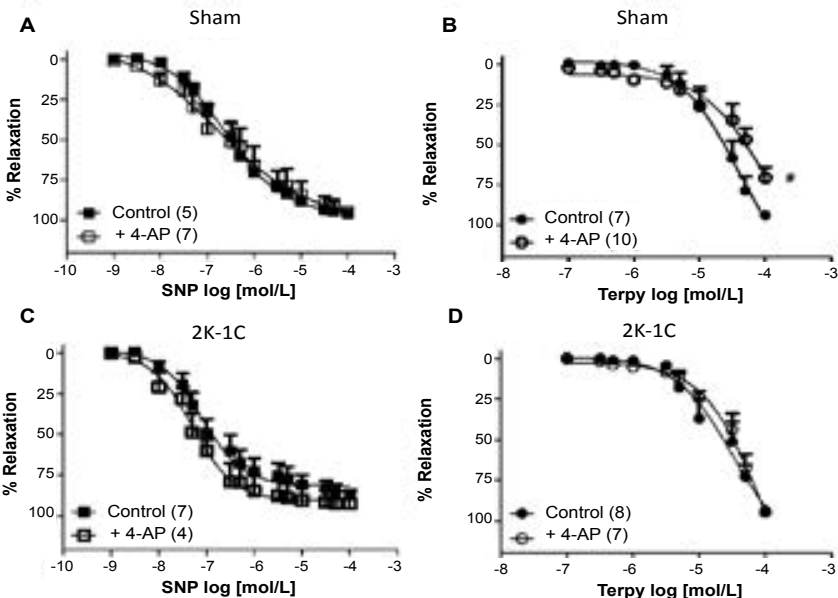

Figure 1: Effect of the selective blockade of the voltage-dependent potassium channels on the relaxation induced by the NO donors SNP and Terpy in mesenteric resistance arteries from Sham (A and $B$ ) and hypertensive $2 \mathrm{~K}-1 \mathrm{C}$ rats $(C$ and $D)$. The curves represent the relaxation response induced by the $\mathrm{NO}$ donor in contracted arterial rings with $10 \mu \mathrm{M}$ phenylephrine, in the absence (control) or in the presence of 4-aminopyridin (4-AP $1 \mathrm{mM})$. The points represent mean \pm SEM of experiments performed in preparations of different animals. The number in parenthesis indicates the $n$ of the experiment. \#statistically different $(p<0.01)$, one-way ANOVA, followed by Newman-Keuls.

$p \mathrm{D}_{2}: 4.08 \pm 0.26, \mathrm{n}=10$, Figure $1 \mathrm{~B}$ ), but not in $2 \mathrm{~K}-1 \mathrm{C}$ rat arteries (ME: $94.6 \pm 2.7 \%, p \mathrm{D}_{2}: 4.04 \pm 0.4, \mathrm{n}=7$, Figure 1D).

The relaxation induced by SNP was not significantly changed by the ATP-sensitive potassium channels blocker glibenclamide, in arteries from Sham (ME: $91.9 \pm 2.8 \%, p \mathrm{D}_{2}: 6.60 \pm 0.30, \mathrm{n}=4$, Figure $2 \mathrm{~A}$ ) or from $2 \mathrm{~K}-1 \mathrm{C}$ rats (ME: $80.4 \pm 6.2 \%, p \mathrm{D}_{2}: 7.20 \pm 0.50, n=5$, Figure $2 \mathrm{C}$ ). However, the maximum relaxation induced by Terpy was decreased by the ATP-sensitive potassium channel blocker glibenclamide, in mesenteric resistance arteries from Sham (ME: $69.5 \pm 5.6 \%, p \mathrm{D}_{2}: 4.25 \pm$ $0.18, \mathrm{n}=8$, Figure $2 \mathrm{~B}$ ) as well in $2 \mathrm{~K}-1 \mathrm{C}$ rat (ME: $72.9 \pm 9.3 \%, p \mathrm{D}_{2}: 4.35$ $\pm 0.13, \mathrm{n}=6$, Figure $2 \mathrm{D}$ ).

The maximum relaxation induced by SNP was not altered by the Small conductance $\mathrm{Ca} 2+$-activated potassium channel blocker apamin, both in arteries from Sham (ME: $85.3 \pm 4.3 \%, p \mathrm{D}_{2}: 6.80 \pm 0.30, \mathrm{n}=4$, Figure $3 \mathrm{~A}$ ) and $2 \mathrm{~K}-1 \mathrm{C}$ rats (ME: $80.9 \pm 5.4 \%, p \mathrm{D}_{2}: 6.52 \pm 0.20, \mathrm{n}=5$, Figure 3C).

The maximum relaxation induced by Terpy was inhibited by the Small conductance $\mathrm{Ca} 2+$-activated potassium channel blocker apamin, both in arteries from Sham (ME: $65.6 \pm 6.2 \%, p \mathrm{D}_{2}: 4.27 \pm 0.34, \mathrm{n}=7$, Figure $3 \mathrm{~B}$ ) and $2 \mathrm{~K}-1 \mathrm{C}$ rats (ME: $74.2 \pm 2.8 \%, p \mathrm{D}_{2}: 4.28 \pm 0.10, \mathrm{n}=4$, Figure 3D).

The maximum relaxation induced by SNP was inhibited by the Large conductance Ca2+-activated potassium channel blocker paxilline, in arteries from Sham (ME: $43.1 \pm 7.6 \%, p \mathrm{D}_{2}: 6.03 \pm 0.19$, $\mathrm{n}=4$, Figure $4 \mathrm{~A}$ ), but not in arteries from $2 \mathrm{~K}-1 \mathrm{C}$ rats (ME: $84.1 \pm 5.4 \%$, $p \mathrm{D}_{2}: 6.85 \pm 0.30, \mathrm{n}=7$, Figure $4 \mathrm{C}$ ).

The maximum relaxation induced by Terpy was inhibited by the Large conductance $\mathrm{Ca} 2+$-activated potassium channel blocker paxilline, both in arteries from Sham (ME: $13.4 \pm 4.1 \%, p \mathrm{D}_{2}: 5.43 \pm$ $0.65, n=5$, Figure $4 \mathrm{~B}$ ) and $2 \mathrm{~K}-1 \mathrm{C}$ rats (ME: $69.5 \pm 9.3 \%, p \mathrm{D}_{2}: 4.04 \pm$ $0.20, n=5$, Figure $4 \mathrm{D})$.
The maximum relaxation induced by SNP was not changed by the inward rectifier potassium channel blocker $\mathrm{BaCl} 2$, in arteries from Sham (ME: $53.8 \pm 6.1 \%, p \mathrm{D}_{2}: 4.32 \pm 0.03, \mathrm{n}=5$, Figure $5 \mathrm{~A}$ ) and from $2 \mathrm{~K}-1 \mathrm{C}$ rats (ME: $76.5 \pm 8.5 \%, p \mathrm{D}_{2}: 6.52 \pm 0.30, n=5$, Figure $5 \mathrm{C}$ ).

The maximum relaxation induced by Terpy was inhibited by the inward rectifier potassium channel blocker $\mathrm{BaCl} 2$, both in arteries from Sham (ME: $53.8 \pm 6.1 \%, p \mathrm{D}_{2}: 4.32 \pm 0.03, \mathrm{n}=5$, Figure $5 \mathrm{~B}$ ) and $2 \mathrm{~K}-1 \mathrm{C}$ rats (ME: $77.5 \pm 7.5 \%, p \mathrm{D}_{2}: 5.09 \pm 0.50, \mathrm{n}=6$, Figure $5 \mathrm{D}$ ).
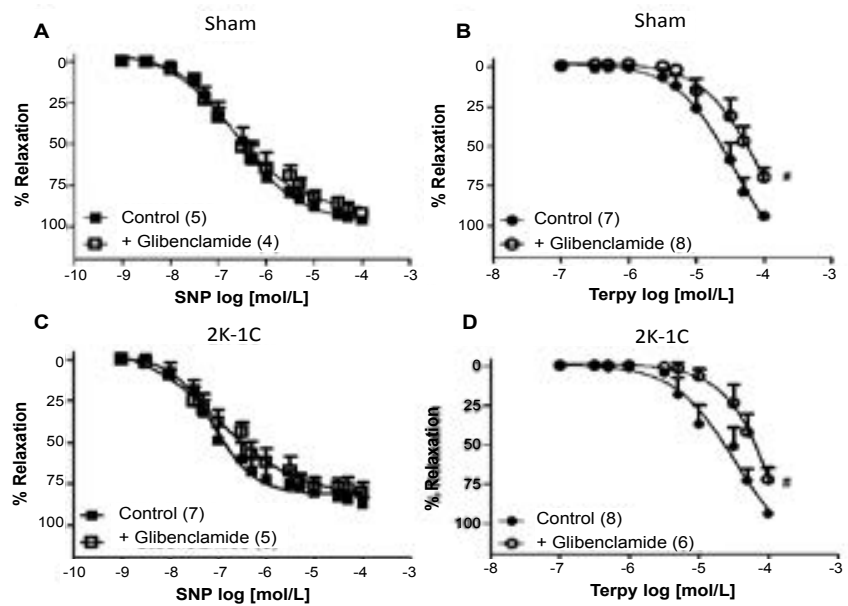

Figure 2: Effect of the selective blockade of the ATP-sensitive potassium channels on the relaxation induced by the NO donors SNP and Terpy in mesenteric resistance arteries from Sham (A and $B$ ) and hypertensive $2 \mathrm{~K}-1 \mathrm{C}$ rats $(\mathrm{C}$ and D). The curves represent the relaxation response induced by the NO donor in contracted arterial rings with $10 \mu \mathrm{M}$ phenylephrine in the absence (control) or in the presence of glibenclamide $(3 \mathrm{mM})$. The points represent mean \pm SEM of in experiments performed in preparations isolated from different animals. The number in parenthesis indicates the $\mathrm{n}$ of experiments. \#statistically different $(p<0.01)$, one-way ANOVA, followed by Newman-Keuls.
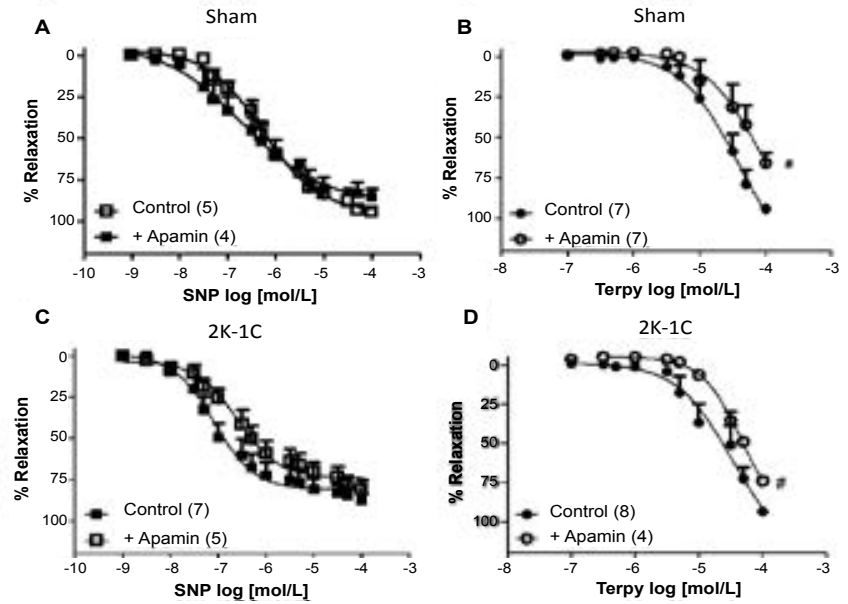

Figure 3: Effect of the selective blockade of the small conductance calciumactivated potassium channels on the relaxation induced by the NO donors SNP and Terpy in mesenteric resistance arteries from Sham (A, B) and hypertensive $2 \mathrm{~K}-1 \mathrm{C}$ rats $(C, D)$. The curves represent the relaxation response induced by the NO donor in contracted arterial rings with $10 \mu \mathrm{M}$ phenylephrine in the absence (control) or in the presence of apamin $(1 \mathrm{mM})$. The points represent mean \pm SEM of experiments performed in preparations of different animals. The number in parenthesis indicates the $\mathrm{n}$ of the experiment. \#statistically different $(p<0.01)$; one-way ANOVA, followed by Newman-Keuls. 

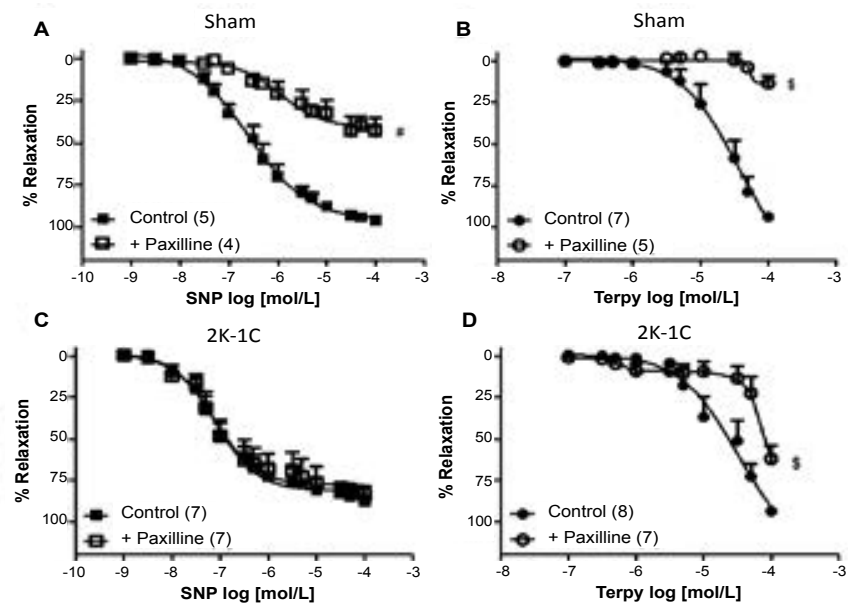

Figure 4: Effect of the selective blockade of the high conductance calciumactivated potassium channels on the relaxation induced by the NO donors SNP and Terpy in mesenteric resistance arteries from Sham (A.B) and hypertensive $2 \mathrm{~K}-1 \mathrm{C}$ (C.D) rats. The curves represent the relaxation response induced by the NO donor in contracted arterial rings with $10 \mu \mathrm{M}$ phenylephrine in the absence (control) or in the presence of paxilline $(1 \mathrm{mM})$. The point represents mean \pm SEM of experiments performed in preparations of different animals The number in parenthesis indicates the $\mathrm{n}$ of the experiment. \#statistically different $(p<0.01)$; $\$$ statistically different $(p<0.001)$; one-way ANOVA, followed by Newman-Keuls.
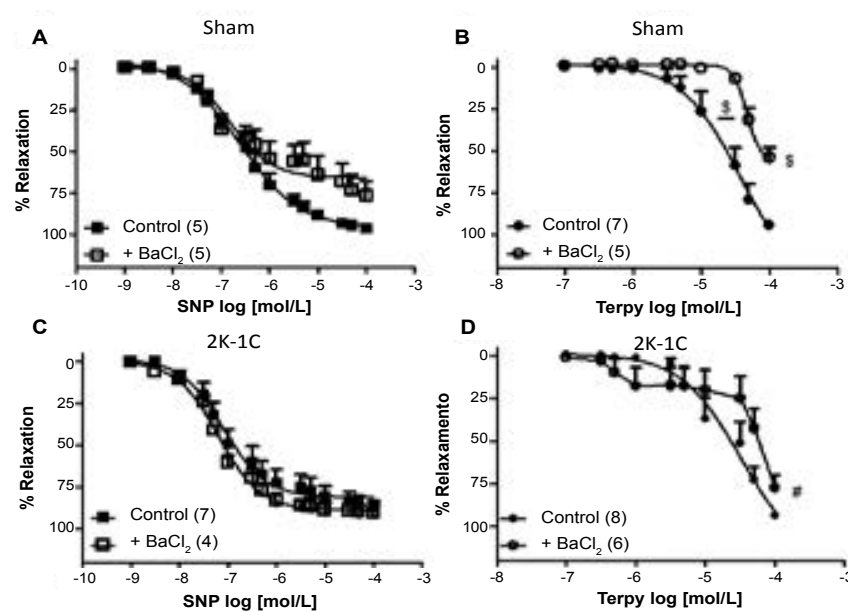

Figure 5: Effect of the selective blockade of inward rectifier potassium channels on the relaxation induced by the NO donors SNP and Terpy in mesenteric resistance arteries from Sham $(A, B)$ and hypertensive $2 \mathrm{~K}-1 \mathrm{C}$ rats $(C, D)$. The curves represent the relaxation induced by the $\mathrm{NO}$ donor in contracted arterial rings with $10 \mu \mathrm{M}$ phenylephrine in the absence (control) or in the presence of $\mathrm{BaCl} 2(30 \mathrm{mM})$. The point represent mean \pm SEM of experiments performed in preparations isolated from different animals. The number in parenthesis indicate the $\mathrm{n}$ of the experiment. \#statistically different $(p<0.01)$; $\$$ statistically different $(p<0.001)$; one-way ANOVA, followed by Newman-Keuls.

\section{Protein expression by Western blotting analysis}

There was no difference on the protein expression of the small conductance calcium-activated potassium channel $\left(\mathrm{SK}_{\mathrm{Ca}}\right)$ and on both subunits (SUR-2B and KIR 6.1) of the ATP-sensitive potassium channel $\left(\mathrm{K}_{\mathrm{ATP}}\right)$ between the mesenteric bed of Sham and $2 \mathrm{~K}-1 \mathrm{C}$ rats. However, the protein expression of the $\mathrm{K}_{\mathrm{v} 1.5}$ subunit of the voltage-dependent potassium channel (KV) and of the big conductance calcium-activated potassium channel $\left(\mathrm{BK}_{\mathrm{Ca}}\right)$ were augmented in the mesenteric bed of $2 \mathrm{~K}-1 \mathrm{C}$ rats when compared to Sham rats (Figure 6).

\section{Discussion}

The microvessels undergo extensive adaptation during the pathogenesis of systemic hypertension. The major finding of this study was to show the functional and expressional pattern of the potassium channels in resistance vessels in $2 \mathrm{~K}-1 \mathrm{C}$ renal hypertensive rats.

Potassium channels play a central role in the maintenance of the electrical potential across the plasma membrane in smooth muscle cells [1]. Voltage-dependent potassium channels $\left(\mathrm{K}_{\mathrm{v}}\right)$ open to allow the efflux of potassium in response to depolarization of the membrane potential, resulting in repolarization and the return to the resting membrane potential [15]. It has been shown that $\mathrm{Kv}$ current from arteries is reduced during SHR, DOCA-salt [11] and Dahl salt-sensitive [16] hypertensive rats. In humans, decreased KV channel function was also shown [17]. Specifically in mesenteric resistance arteries, it was observed a smaller current through KV in SHR than in Wistar Kyoto rats (WKY) [18]. In the same way, in our study, the blockade of KV inhibited the response induced by Terpy in mesenteric resistance arteries from Sham, but not from $2 \mathrm{~K}-1 \mathrm{C}$ rats, suggesting an impaired function of these channels.

Regarding the protein expression, Cox et al. [19] have shown that the protein expression of $\mathrm{K}_{\mathrm{V} 1.5}$ subunit of $\mathrm{KV}$ was not different between aortas from SHR and WKY rats, but it was higher in mesenteric resistance arteries from SHR. They have also shown that the $\mathrm{K}_{v}$ currents associated with Kv1.X and Kv2.1 channels were both larger in mesenteric arteries myocytes from SHR, but less than expected based upon differences in KV protein expression. On the other hand,

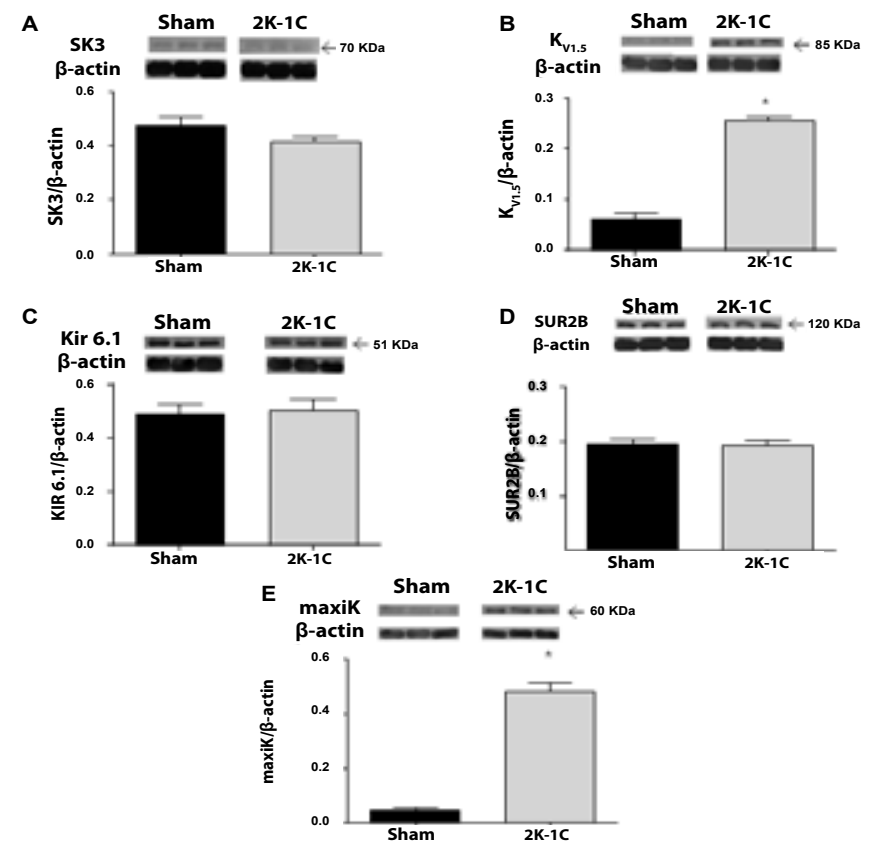

Figure 6: Protein expression of the $\mathrm{SK}_{\mathrm{C}}$ (A), $\mathrm{K}_{\mathrm{V} \text {, }}$ subunit of $\mathrm{KV}(\mathrm{B}), \mathrm{KIR6} .1$ (C) and SUR-2B (D) subunits of KATP and BK $(E)$ in the mesenteric bed isolated from Sham and $2 \mathrm{~K}-1 \mathrm{C}$ rats. Determinations were made by Western blotting technique. Each lane represents the protein obtained from a sample from $(n=6)$ different animals. The bars represent the densitometry of the blots corrected by $\beta$-actin. *statistically different of Sham $(p<0.05)$ by unpaired $t$ Student test. 
[20] have observed that the $\mathrm{K}_{\mathrm{v} 1.5}$ subunit expression is smaller in hypertensive rats induced by administration of N-nitro-arginine. In our study, although the function of KV seems to be impaired, we have observed that protein expression of the $\mathrm{K}_{\mathrm{v} 1.5}$ subunit was increased in the mesenteric bed from $2 \mathrm{~K}-1 \mathrm{C}$ rats, when compared to Sham rats. Cox and Rusch [21] have also shown a functional downregulation of smooth muscle KV channels in hypertension, despite evidence that expression of the channel protein is increased. We may suggest that this augmented protein expression could be a compensatory mechanism in this vessels in this experimental model of hypertension.

Another type of potassium channels expressed in the vascular smooth muscle cells are the calcium-activated potassium channels, which may be of small conductance $\left(\mathrm{SK}_{\mathrm{Ca}}\right)$ or big conductance $\left(\mathrm{BK}_{\mathrm{Ca}}\right)$. $\mathrm{BK}_{\mathrm{Ca}}$ are activated by membrane depolarization or by augmented intracellular calcium concentration [22-24]. A number of vasodilators, including $\mathrm{NO}$, seems to activate $\mathrm{BK}_{\mathrm{C}}$ channels in some systems either directly $[25,26]$, or by activation of protein kinases [27].

Resistance arteries exist physiologically in a partially constricted state, from which they constrict further or dilate, to respond to the perfusion needs of the tissue or organ. A major physiological stimulus for constriction is intravascular pressure [28]. Resistance arteries respond to an elevation in intravascular pressure by a graded membrane depolarization, elevation in $\left[\mathrm{Ca}^{2+}\right] \mathrm{i}$, and constriction, which is dependent on the increased calcium entry through voltagedependent calcium channels [29]. A number of negative feedback mechanisms are linked to the increase in VSMC $\left[\mathrm{Ca}^{2+}\right] \mathrm{i}$, including the activation of $\mathrm{BK}_{\mathrm{Ca}}$ channels [30].

The function of the $\mathrm{BK}_{\mathrm{C}}$ has been shown to be augmented in SHR [31-33]. Rusch et al [34] and England et al. [35] demonstrated that SHR aortic smooth muscle cells have more $\mathrm{K}_{\mathrm{Ca}}$ current than WKY cells. Then, other studies $\left[36,37\right.$ ) provided evidence that the increased $\mathrm{BK}_{\mathrm{Ca}}$ current in aortic smooth muscle cells from SHR and salt-sensitive hypertensive rats was the result of increased $\mathrm{Ca}^{2+}$ influx and/or transmembrane $\mathrm{Ca}^{2+}$ cycling and suggested that it may be a compensatory mechanism to counterbalance the augmented contraction that occurs in hypertension and prevent organ damage. This phenomenon occurs similarly throughout the vasculature, including the aorta [34] (Rusch et al., 1992) carotid, mesenteric, femoral [38], and cerebral vascular beds [39]. Therefore, increased $\mathrm{BK}_{\mathrm{Ca}}$ channel function in arterial smooth muscle cells may provide a protective mechanism against progressive increases in blood pressure. This negative-feedback mechanism would modulate increased pressure and vascular tone, and subsequently limit pressure-induced vasoconstriction and preserve local blood flow.

However, Kang et al. [40] have shown that the function of $\mathrm{BK}_{\mathrm{Ca}}$ is impaired in mesenteric resistance arteries from various models of hypertension (angiotensin II-infused, associated or not to an augmented ingestion of salt, and DOCA-salt hypertension), although the nitric oxide pathway compensates to maintain vasorelaxation in these arteries through NOS-mediated cGMP and $\mathrm{H}_{2} \mathrm{O}_{2}$ production. Similarly, we have previously observed that the relaxation induced by Terpy is not impaired in the mesenteric resistance arteries from $2 \mathrm{~K}$ $1 \mathrm{C}$ hypertensive rats [41]. However, in the present study, the blockade of $\mathrm{BK}_{\mathrm{Ca}}$ inhibited the mesenteric resistance arteries relaxation induced by SNP in Sham, but not in $2 \mathrm{~K}-1 \mathrm{C}$ rats and the inhibition caused by the blockade of $\mathrm{BK}_{\mathrm{Ca}}$ is smaller in $2 \mathrm{~K}-1 \mathrm{C}$ when compared to Sham rats. These data suggest an impaired function in these channels in mesenteric resistance arteries in this model of hypertension.

Some studies have reported an augmented expression of the
$\mathrm{BK}_{\mathrm{Ca}}$ during hypertension, but most of them were conducted in large vessels $[42,43]$. Similarly to what happens to KV, in our study, the protein expression of $\mathrm{BK}_{\mathrm{C}}$ is augmented in the mesenteric bed of $2 \mathrm{~K}-1 \mathrm{C}$ hypertensive rats. This augmented expression with decreased effect of the blocker paxilline may suggest that there is a functional downregulation of this subtype of potassium channels.

It is important to notice that although the molecular weight of $\mathrm{BK}_{\mathrm{Ca}}$ is $125 \mathrm{kD}$, we have observed in the Western blotting studies a band in $60 \mathrm{kD}$. Similarly, Garcia-Calvo et al. [44] have observed that the $\mathrm{BK}_{\mathrm{Ca}}$ on tracheal smooth muscle appeared in $60 \mathrm{kD}$. Knaus et al. [45] have shown that it occurs due to the proteolysis caused by the extraction process.

There is a paradigm for "ion channel remodeling" in hypertension, which may be regarded as the change in surface density of $\mathrm{Ca}^{2+}$ and potassium channels in the vascular smooth muscle cells membrane associated with the chronic elevation of blood pressure, according to Cox and Rusch [21]: First, the upregulation of L-Type $\mathrm{Ca}^{2+}$ channels and/or loss of KV channels have been proposed as key excitatory events that result in membrane depolarization and increased voltage-gated $\mathrm{Ca}^{2+}$ influx in arteries exposed to high blood pressure. Subsequently, the compensatory overexpression of $\mathrm{BK}_{\mathrm{Ca}}$ channels is thought to provide a counter-regulatory mechanism to help prevent local vasospasm and ischemic episodes in hypertensive disease. Taking into account these findings, we may suggest that these channels are more expressed and do not have their function impaired in mesenteric resistance arteries during $2 \mathrm{~K}-1 \mathrm{C}$ hypertension.

Some microvascular smooth muscle cells may also express small conductance $\mathrm{K}_{\mathrm{Ca}}\left(\mathrm{SK}_{\mathrm{Ca}}\right)$ channels [46]. The physiological function of these channels in vascular smooth muscle is not fully understood. $\mathrm{SK}_{\mathrm{C}}$ may be presented as SK1, SK2 and SK3. SK3 is the most expressed in vascular smooth muscle cells [47]. In our study, we have observed that these channels do not participate of the relaxation induced by SNP but they participate of the relaxation induced by Terpy. However, there is no difference between hypertensive $2 \mathrm{~K}-1 \mathrm{C}$ and normotensive rat arteries. Moreover, the protein expression of these channels was not different between $2 \mathrm{~K}-1 \mathrm{C}$ and Sham arteries.

Another type of $\mathrm{K}^{+}$channels is the ATP-sensitive potassium channels $\left(\mathrm{K}_{\text {ATP }}\right)$, They are inhibited by cytosolic ATP and they also appear to play a role in the mechanism of action of vasodilators $[24,48]$ (Jackson, 1993, JACKSON ET AL 1993), including NO [22]. They are voltage-independent channels. In hypertensive states, the $\mathrm{K}_{\text {атp }}$ may have their function impaired, as shown by Gosh et al. [49] in aortas from DOCA-salt hypertensive rats. Synthetic $\mathrm{K}_{\mathrm{ATP}}$ channel activators are less potent dilators in vivo in both large [50] and small cerebral vessels [51] of chronically hypertensive rats. On the other hand, Blanco-Rivero et al. [52] have shown that the protein expression of $\mathrm{K}_{\text {ATP }}$ was lower in aorta from SHR when compared to WKY, although the function of these channels were preserved. Moreover, one study reported enhanced $\mathrm{K}_{\mathrm{ATP}}$ channel function in SHR [53]. In the present study, the blockade of $\mathrm{K}_{\text {ATP }}$ alone did not alter the relaxation induced by SNP and the participation of $\mathrm{K}_{\mathrm{ATP}}$ on the relaxation induced by Terpy was not different between arteries from Sham and $2 \mathrm{~K}-1 \mathrm{C}$ rats, suggesting that their function is not impaired in $2 \mathrm{~K}-1 \mathrm{C}$ hypertension. The $\mathrm{K}_{\mathrm{ATP}}$ from vascular smooth muscle cells are composed of a tetramer of KIR 6.1 subunits that form the ion conductive pore, and complementary regulatory sulfonylurea receptor (SUR) subunits, SUR 2B [1,54]. The subunit KIR6.2 has also been found [55]. The protein expression of the subunits of KATP was not changed in arteries from $2 \mathrm{~K}-1 \mathrm{C}$ rats in our study. 
The inward rectifier family of potassium channels $\left(\mathrm{K}_{\mathrm{IR}}\right)$ is divided into seven subfamilies ( $\mathrm{K}_{\mathrm{IR}} 1.0$ to $\mathrm{K}_{\mathrm{IR}} 7.0$ ), but the KIR 2.0 subfamily is the most relevant to the blood vessel wall. In the vascular wall, $\mathrm{K}_{\mathrm{IR}}$ channels are expressed in both the endothelial and in the smooth muscle cells [56]. KIR channels are abundant in the smooth muscle of smalldiameter resistance vessels $[3,57]$. For example, the currents through KIR in the smooth muscle cells from coronary arteries augment from the conductance until the small resistance arteries [3]. This difference in the protein expression explains the fact that the conductance arteries present small response to small augments in extracellular potassium, while the resistance arteries present great dilatation $[3,58]$.

There is evidence that vascular $\mathrm{K}_{\mathrm{IR}}$ channels function may be impaired in hypertension. McCarron and Halpern [59] reported that the barium-sensitive vasodilator responses to potassium were impaired in posterior cerebral arteries from SHR when compared to WKY. However, in our study, the blockade of $\mathrm{K}_{\mathrm{IR}}$ impaired the relaxation induced by Terpy but not to SNP, in a similar way in Sham and $2 \mathrm{~K}-1 \mathrm{C}$ hypertensive rats.

As can be seen, the inhibition of none of the channels alone was able to inhibit the relaxant response induced by SNP. However, the blockade of the channels in a non-selective way with TEA, the relaxation was impaired (data not shown). We suggest that there should be a compensatory mechanism to guarantee the relaxation even if one channel subtype is impaired. Taking into account that it did not happen to the relaxation induced by Terpy, we may also conclude that the activation of potassium channels is a mechanism more important to the relaxation induced by Terpy than it is for SNP.

Experimental hypertension models enable development of targeted interventions in order to decrease blood pressure [60]. The animal model for hypertension research should have human-like disease characteristics and complications [61]. Renovascular hypertension $2 \mathrm{~K}-1 \mathrm{C}$ is a non-genetic model that is influenced by renin-angiotensinaldosterone system. Renovascular hypertension is among the most common causes of secondary hypertension [62].

There are several experimental hypertension models developed which simulate the impaired NO production/availability together with another vascular alterations reported to endothelial dysfunction, including in $2 \mathrm{~K}-1 \mathrm{C}$. The classic nitrovasodilators organic nitrate and nitrite esters, including nitroglycerin, amyl nitrite and isosorbide dinitrate have been employed for many years in cardiovascular diseases treatment, but their use is limited due to tolerance and/or side effects.

Considering the relevance of the resistance vessels in regulating arterial pressure, it was of great interest to investigate the vascular relaxation induced by the new NO donor (Terpy) in mesenteric resistance artery from hypertensive and normotensive rats. Activation of potassium $\left(\mathrm{K}^{+}\right)$channels is one of the major mechanisms of NOinduced vasodilation. For our surprise, the vascular relaxation was not impaired in renal hypertensive as compared to normotensive as it was observed in conductance vessels. It could be explained by the fact that several types of $\mathrm{K}+$ channels are activated in both hypertensive and normotensive rats mesenteric arteries. However, only in hypertensive mesenteric artery, voltage-dependent $\mathrm{K}^{+}$channels $\left(\mathrm{K}_{\mathrm{v}}\right)$ are activated. It can be relevant for human hypertension, since $\mathrm{K}^{+}$channels $\left(\mathrm{K}_{\mathrm{v}}\right)$ could be a target for nitrovadilators clinically used to treat hypertension. In addition, Terpy does not induce citotoxity to vascular smooth muscle cells in the concentrations used to induce vasorelaxation (unpublished data).

In conclusion, SNP and Terpy induce relaxation of mesenteric resistance arteries by activation of different potassium channels. Moreover, the function and protein expression of different potassium channels may be differently changed during hypertension.

\section{Aknowledgement}

We thank Dr. Juliana C. Biazzotto for synthesize the compound Terpy. This work was supported by grants from Fundação de Amparo à Pesquisa do Estado de São Paulo (FAPESP) and Conselho Nacional de Desenvolvimento Científico e Tecnológico (CNPq).

\section{References}

1. Standen NB, Quayle JM (1998) K+ channel modulation in arterial smooth muscle. Acta Physiol Scand 164: 549-557.

2. Archer SL, Huang JMC, Reeve HL, Hampl V, Tolarova S, et al. (1996) Differential distribution of electrophysiologically distinct myocytes in conduit and resistance arteries determines their response to nitric oxide and hypoxia. Circ Res 78: 431-441.

3. Quayle JM, Dart C, Standen NB (1996) The properties and distribution of inward rectifier potassium currents in pig coronary arterial smooth muscle. $J$ Physiol 494: 715-726.

4. Bowles DK, Hu Q, Laughlin MH, Sturek M (1997) Heterogeneity of L-type calcium current density in coronary smooth muscle. Am J Physiol 273: H20832089.

5. Jackson WF, Blair KL (1998) Characterization and function of $\mathrm{Ca}(2+)$-activated $\mathrm{K}+$ channels in arteriolar muscle cells. Am J Physiol 274: H27-34.

6. Michelakis ED, Reeve HL, Huang JM, Tolarova S, Nelson DP, et al. (1997) Potassium channel diversity in vascular smooth muscle cells. Can J Physio Pharmacol 75: 889-897.

7. Jackson WF (2005) Potassium channels in the peripheral microcirculation Microcirculation 12: 113-127.

8. Matsumoto T, Szasz T, Tostes RC, Webb RC (2012) Impaired $\hat{I}^{2}$-adrenoceptorinduced relaxation in small mesenteric arteries from DOCA-salt hypertensive rats is due to reduced $\mathrm{K}(\mathrm{Ca})$ channel activity. Pharmacol Res 65: 537-545.

9. Shoemaker RL, Overbeck HW (1986) Vascular smooth muscle membrane potential in rats with early and chronic one-kidney, one-clip hypertension. Proc Soc Exp Biol Med 181: 529-534.

10. Callera GE, Varanda WA, Bendhack LM (2000) Impaired relaxation to acetylcholine in $2 \mathrm{~K}-1 \mathrm{C}$ hypertensive rat aortas involves changes in membrane hyperpolarization instead of an abnormal contribution of endothelial factors. Gen Pharmacol 34: 379- 389.

11. Martens JR, Gelband $\mathrm{CH}$ (1996) Alterations in rat interlobar artery membrane potential and $\mathrm{K}+$ channels in genetic and nongenetic hypertension. Circ Res 79: 295-301.

12. Cox RH (2002) Changes in the expression and function of arterial potassium channels during hypertension. Vascul Pharmacol 38: 13-23.

13. Mulvany MJ, Halpern W (1977) Contractile properties of small arteria resistance vessels in spontaneously hypertensive and normotensive rats. Circ Res 41: 19-26.

14. de Lima RG, Sauaia M, Bonaventura D, Tedesco AC, Bendhack LM, et at. (2006) Influence of ancillary ligand $L$ in the nitric oxide photo-release by the $[\mathrm{Ru}(\mathrm{L})($ terpy)NO $3+$ complex and its vasodilator activity based on visible light irradiation. Inorg Chim Acta 359: 2543-2549.

15. Ko EA, Han J, Jung ID, Park WS (2008) Physiological roles of $\mathrm{K}+$ channels in vascular smooth muscle cells. J Smooth Muscle Res 44: 65-81.

16. Wellman GC, Cartin L, Eckman DM, Stevenson AS, Saundry CM, et al. (2001) Membrane depolarization, elevated $\mathrm{Ca}(2+)$ entry, and gene expression in cerebral arteries of hypertensive rats. Am J Physiol Heart Circ Physiol 281 H2559-2567.

17. Yuan X-J, Aldinger AM, Juhaszova M, Wang J, Conte JVJ, et al. (1998) Dysfunctional voltage-gated $\mathrm{K} 1$ channels in pulmonary artery smooth muscle cells of patients with primary pulmonary hypertension. Circulation 98: 1400 1406.

18. Cox RH, Folander K, Swanson R (2001) Differential expression of voltagegated $\mathrm{K}(+)$ channel genes in arteries from spontaneously hypertensive and Wistar-Kyoto rats. Hypertension 37: 1315-1322. 
Citation: Araújo AV, Grando MD, Silva RSDA, Bendhack LM (2014) Function and Protein Expression of Potassium Channels in Mesenteric Resistance Arteries Isolated from 2K-1C Hypertensive Rats. J Hypertens 3: 146. doi:10.4172/2167-1095.1000146

19. Cox RH, Fromme SJ, Folander KL, Swanson RJ (2008) Voltage gated K+ channel expression in arteries of Wistar-Kyoto and spontaneously hypertensive rats. Am J Hypertens 21: 213-218.

20. Bratz IN, Dick GM, Partridge LD, Kanagy NL (2005) Reduced molecula expression of $\mathrm{K}+$ channel proteins in vascular smooth muscle from rats made hypertensive with N?nitro-L-arginine. Am J Physiol 289: H1277-H1283.

21. Cox RH, Rusch NJ (2002) New expression profiles of voltage-gated ion channels in arteries exposed to high blood pressure. Microcirculation 9: 243-257.

22. Nelson MT, Quayle JM (1995) Physiological roles and properties of potassium channels in arterial smooth muscle. Am J Physiol 268: C799-822.

23. Jackson WF (2000) lon channels and vascular tone. Hypertension 35: 173-178.

24. Jackson WF (1993) Arteriolar tone is determined by activity of ATP-sensitive potassium channels. Am J Physiol 265: H1797-1803.

25. Mistry DK, Garland CJ (1998) Nitric oxide (NO)-induced activation of large conductance $\mathrm{Ca} 2+$-dependent $\mathrm{K}+$ channels $(\mathrm{BK}(\mathrm{Ca}))$ in smooth muscle cells isolated from the rat mesenteric artery. Br J Pharmacol 124: 1131-1140.

26. Bolotina VM, Najibi S, Palacino JJ, Pagano PJ, Cohen RA (1994) Nitric oxide directly activates calcium-dependent potassium channels in vascular smooth muscle. Nature 368: 850-853.

27. Archer SL, Huang JM, Hampl V, Nelson DP, Shultz PJ, et al. (1994) Nitric oxide and cGMP cause vasorelaxation by activation of a charybdotoxin-sensitive $K$ channel by cGMP-dependent protein kinase. Proc Natl Acad Sci U S A 91: 7583-7587.

28. Bayliss WM (1902) On the local reaction of the arterial wall to changes of internal pressure. J Physiol 28: 228-231.

29. Nelson MT, Patlak JB, Worley JF, Standen NB (1990) Calcium channels potassium channels, and voltage dependence of arterial smooth muscle tone. Am J Physiol 259: C3-18.

30. Brayden JE, Nelson MT (1992) Regulation of arterial tone by activation of calcium-dependent potassium channels. Science 256: 532-535.

31. Jones AW (1973) Altered ion transport in vascular smooth muscle from spontaneously hypertensive rats. Influences of aldosterone, norepinephrine, and angiotensin. Circ Res 33: 563-572.

32. Jones AW, Hart RG (1975) Altered ion transport in aortic smooth muscle during deoxycorticosterone acetate hypertension in the rat. Circ Res 37: 333-341.

33. Smith JM, Jones AW (1990) Calcium antagonists inhibit elevated potassium efflux from aorta of aldosterone-salt hypertensive rats. Hypertension 15: 78-83.

34. Rusch NJ, De Lucena RG, Wooldridge TA, England SK, Cowley AW Jr (1992) A Ca(2+)-dependent $\mathrm{K}+$ current is enhanced in arterial membranes of hypertensive rats. Hypertension 19: 301-307.

35. England SK, Wooldridge TA, Stekiel WJ, Rusch NJ (1993) Enhanced singlechannel $\mathrm{K}+$ current in arterial membranes from genetically hypertensive rats. Am J Physiol 264: H1337-1345.

36. Liu Y, Jones AW, Sturek M (1994) Increased barium influx and potassium current in stroke-prone spontaneously hypertensive rats. Hypertension 23 1091-1095.

37. Liu Y, Jones AW, Sturek M (1995) Ca(2+)-dependent K+ current in arteria smooth muscle cells from aldosterone-salt hypertensive rats. Am J Physiol 269 H1246-1257.

38. Asano M1, Masuzawa-lto K, Matsuda T, Suzuki Y, Oyama H, et al. (1993) Functional role of charybdotoxin-sensitive $\mathrm{K}+$ channels in the resting state of cerebral, coronary and mesenteric arteries of the dog. J Pharmacol Exp Ther 267: 1277-1285.

39. Paternò R, Heistad DD, Faraci FM (1997) Functional activity of Ca2+-dependent $\mathrm{K}+$ channels is increased in basilar artery during chronic hypertension. Am J Physiol 272: H1287-1291.

40. Kang KT, Sullivan JC, Sasser JM, Imig JD, Pollock JS (2007) Novel nitric oxide synthase--dependent mechanism of vasorelaxation in small arteries from hypertensive rats. Hypertension 49: 893-901.

41. Araújo AV, Pereira AC, Grando MD, da Silva RS, Bendhack LM (2013) The new NO donor Terpy induces similar relaxation in mesenteric resistance arteries of renal hypertensive and normotensive rats. Nitric Oxide 35: 47-53.
42. Liu Y, Pleyte K, Knaus HG, Rusch NJ (1997) Increased expression of Ca2+sensitive $\mathrm{K}+$ channels in aorta of hypertensive rats. Hypertension 30: 14031409.

43. Chang T, Wu L, Wang R (2006) Altered expression of BK channel beta1 subunit in vascular tissues from spontaneously hypertensive rats. Am J Hypertens 19 678-685.

44. Garcia-Calvo M, Knaus HG, McManus OB, Giangiacomo KM, Kaczorowski GJ, et al. (1994) Purification and reconstitution of the high-conductance, calciumactivated potassium channel from tracheal smooth muscle. J Biol Chem 269 676-682.

45. Knaus HG, Eberhart A, Koch RO, Munujos P, Schmalhofer WA, et al. (1995) Characterization of tissue-expressed alpha subunits of the high conductance $\mathrm{Ca}(2+)$-activated K+ channel. J Biol Chem 270: 22434-22439.

46. Carl A, Lee HK, Sanders KM (1996) Regulation of ion channels in smooth muscles by calcium. Am J Physiol 271: C9-34.

47. Bond CT, Maylie J, Adelman JP (1999) Small-conductance calcium-activated potassium channels. Ann N Y Acad Sci 868: 370-378.

48. Jackson WF, König A, Dambacher T, Busse R (1993) Prostacyclin-induced vasodilation in rabbit heart is mediated by ATP-sensitive potassium channels. Am J Physiol 264: H238-243.

49. Ghosh M, Hanna ST, Wang R, McNeill JR (2004) Altered vascular reactivity and KATP channel currents in vascular smooth muscle cells from deoxycorticosterone acetate (DOCA)-salt hypertensive rats. J Cardiovasc Pharmacol 44: 525-531.

50. Kitazono T, Heistad DD, Faraci FM (1993) ATP-sensitive potassium channels in the basilar artery during chronic hypertension. Hypertension 22: 677-681.

51. Takaba H, Nagao T, Ibayashi S, Kitazono T, Fujii K, et al. (1996) Altered cerebrovascular response to a potassium channel opener in hypertensive rats. Hypertension 28: 143-146.

52. Blanco-Rivero J, Gamallo C, Aras-López R, Cobeño L, Cogolludo A, et al. (2008) Decreased expression of aortic KIR6.1 and SUR2B in hypertension does not correlate with changes in the functional role of K(ATP) channels. Eur J Pharmacol 587: 204-208.

53. Miyata N, Tsuchida K, Otomo S (1990) Functional changes in potassium channels in carotid arteries from stroke-prone spontaneously hypertensive rats. Eur J Pharmacol 182: 209-210.

54. Babenko AP, Aguilar-Bryan L, Bryan J (1998) A view of sur/KIR6.X, KATP channels. Annu Rev Physiol 60: 667-687.

55. Gao M, Xue H, Wang Y, Wang H (2005) Iptakalim, opener of K(ATP), reverses the enhanced expression of genes encoding K(ATP) subunits in spontaneously hypertensive rats. Life Sci 77: 2743-2751.

56. Quayle JM, McCarron JG, Brayden JE, Nelson MT (1993) Inward rectifier K+ currents in smooth muscle cells from rat resistance-sized cerebral arteries. Am J Physiol 265: C1363-1370.

57. Knot HJ, Zimmermann PA, Nelson MT (1996) Extracellular K(+)-induced hyperpolarizations and dilatations of rat coronary and cerebral arteries involve inward rectifier $\mathrm{K}(+)$ channels. J Physiol 492 : 419-430.

58. Quayle JM, Nelson MT, Standen NB (1997) ATP-sensitive and inwardly rectifying potassium channels in smooth muscle. Physiol Rev 77: 1165-1232.

59. McCarron JG, Halpern W (1990) Impaired potassium-induced dilation in hypertensive rat cerebral arteries does not reflect altered $\mathrm{Na}+, \mathrm{K}(+)$-ATPase dilation. Circ Res 67: 1035-1039.

60. Lerman LO, Chade AR, Sica V, Napoli C (2005) Animal models of hypertension: an overview. J Lab Clin Med 146: 160-173.

61. White CJ, Ramee SR, Banks AK, Wiktor D, Price HL (1992) The Yucatán Miniature Swine: an atherogenic model to assess early patency rates of an endovascular stent. In: Swindle MM, Moody DC, Phillips LD Swine as models in biochemical research. Ames, lowa: lowa State University Press 156-162.

62. Krishna A, Kumar O, Singh MK (2013) Renovascular hypertension: A review article. Clin Queries Nephrology 2: 38-43. 